\title{
Perception of performance and importance to consumers agro-industry of family companies in the northern region of Rio Grande do Sul state
}

\section{Raquel Breitenbach ${ }^{1}$ Andréa Bündchen ${ }^{2}$ Janaína Balk Brandão $^{3}$ Leonardo Marques Caires ${ }^{4}$}

\author{
${ }^{1}$ Instituto Federal do Rio Grande do Sul, Campus Sertão, 99170-000, Sertão, RS, Brasil. E-mail: raquel.breitenbach@sertao.ifrs.edu.br. \\ ${ }^{*}$ Corresponding author. \\ ${ }^{2}$ Instituto Federal de Educação, Ciência e Tecnologia do Rio Grande do Sul, Sertão, RS, Brasil. \\ ${ }^{3}$ Departamento de Educação Agrícola e Extensão Rural, Universidade Federal de Santa Maria (UFSM), Santa Maria, RS, Brasil. \\ ${ }^{4}$ Programa de Pós-graduação em Engenharia de Produção, Universidade Federal de Santa Maria (UFSM), Santa Maria, RS, Brasil.
}

\begin{abstract}
The aim of this study was to identify the strategic direction of agroprocessing enterprises and the level of compliance with consumer requirements, as well as the position of agro-industry enterprises in relation to their primary competitors. To this end, a survey was performed, which included nine family agro-industry enterprises from the Northern region of Rio Grande do Sul (RS) and their respective buyers. For this research, the Importance-Performance Matrix methodology described by SLACK (2002) was used. The strategy of the analyzed agro-industry enterprises relies on differentiation, presenting most of the items studied in accordance with consumers'demands. Consequently, they are not at a disadvantage to their competitors in most criteria that consumers consider fundamental at the time of purchase.

Key words: agro-industries family, importance-performance matrix, competitiveness, strategic orientation, strategic positioning, northern Rio Grande do Sul.
\end{abstract}

Percepção de desempenho e importância para consumidores de agroindústrias familiares na região norte

RESUMO: O objetivo desta pesquisa é identificar qual a orientação estratégica das empresas agroindustriais e o nível de conformidade com as exigências dos consumidores, bem como, qual sua posição em relação aos principais concorrentes. Para tanto, foi realizada uma pesquisa com nove agroindústrias familiares da Região Norte do Rio Grande do Sul (RS) e seus respectivos compradores. Para esta pesquisa foi utilizada a metodologia da matriz Importância X Desempenho de SLACK. A orientação estratégica das agroindústrias analisadas é a a diferenciação, apresentando na maioria dos itens estudados conformidade com as exigências dos consumidores. Ou seja, a posição das mesmas não está em desvantagem com seus concorrentes para a maioria dos critérios considerados fundamentais para os consumidores na hora de optar pela compra.

Palavras-chave: agroindústrias familiares, matriz importância $x$ desempenho, competitividade, orientação estratégica, posicionamento estratégico, Norte do Rio Grande do sul.

\section{INTRODUCTION}

In competitive environments, enterprises competing with established businesses need to identify strategies to survive and grow in the market. They adopt development strategies that result in increased competition between sectors and between enterprises themselves.

This fact can also be applied to agroindustry enterprises. Family agro-industry enterprises find their origin in the colonial tradition of food processing for domestic consumption. However, the main drivers of the recent changes in small and medium-sized rural agroprocessing enterprises have the necessity of evolving to account for structural changes in vertical integration networks between family farmers and agribusiness enterprises and growing institutionalization of family farming (MIOR, 2005; WILKINSON, 2008;).

Therefore, when the analytical approach is the family agroindustries, the particularities are greater. Usually these businesses work with smaller productive scale; they commercialize in more regionalized markets; their business strategies are 
more successful when focusing on consumers who value the local production, the origin of the raw material and the commercialization places.

Because the analytical sample consists of family agroindustries, the level of detail is high, because these enterprises usually work at a small production scale, commercialize in regionalized markets. In these cases, to have greater success, in terms of business strategies, they focus on consumers, who value their specific attributes, such as, local production, origin of raw material, and marketing sites.

A new course of action for these enterprises is based largely on increased competition and the need for competitive gains. Thus, enterprises operating in the agribusiness market, like other enterprises operating in the business world, require the constant effort of managers to seek competitive advantages over competitors. However, many organizations neglect analyses of their external environments, especially in relation to their customers and competitors, who are critical to the success of their goals and the determination of their strategies.

Based on these concerns, the objective of this research is to identify the strategic direction of family agroprocessing enterprises and their level of compliance with the demands of consumers, as well as their position in relation to key competitors in the northern region of the state of Rio Grande do Sul. For this purpose, a survey of family agroindustries and their buyers was conducted in the northern region of the state of Rio Grande do Sul (RS). This research used the methodology of the Importance-Performance matrix of SLACK (2002), which is considered an efficient tool to achieve the proposed goals.

The specific objectives of this research project are as follows: identify the dimensions and competitive criteria most valued by consumers; verify the dimensions and competitive criteria on which agroprocessing enterprises concentrate their competitive strategies; analyze the existing level of agreement between competitive criteria valued by customers, competitive criteria strategically prioritized by agroprocessing enterprises, and enterprises' positions relative to their main competitors; and identify criteria that require urgent action, as well as those that need improvement.

The importance of studies focusing on family agro-industry enterprises is demonstrated by the changes in the habits of consumers, who increasingly value local products with known origins. These conditions demonstrated the need to structure short marketing circuits, which support regional supply and development.
It is necessary to define the terms competition and competitiveness: competitiveness is the competence of a system, which may be represented by a specific company, a group of enterprises, an industrial sector, or even a country, to act without failing in a market (WOOD, Jr. \& CALDAS, 2007); competition is the confrontation between organizations in an economic environment, which together forms an industry or a arket (Lisboa et al., 2009). Competition stimulates economic systems, causing enterprises to reduce costs and to seek constant technological development and quality improvement as competitive gain strategies. In more competitive markets, enterprises have a greater need to investment in strategies that create competitive advantages vis-à-vis their competition, and from the perspective of their consumers (AZEVEDO, 2000). To PORTER (1989), a strategy is the search for an appropriate competitive position in a market, in which competition is the essence of the success or failure of organizations.

Competitive advantage is a result of the value that a company brings via products and services provided to consumers, which should be greater than the cost of production. PORTER (1989) stated that there are two types of competitive advantage, differentiation and cost leadership, that, when aligned with a company's scope of activities, result in three generic strategies in the search for above-average performance: differentiation, cost leadership and focus. The author proposed that each generic strategy achieves competitive advantage in a fundamentally different way. Consequently, a company defines the type of competitive advantage it seeks, and the market scope in which to achieve it.

The segment of the family agroindustry is composed by small producers of food of plant and animal origin, who may be organic or not, as well as pastas and bakery products. They are generally micro and small businesses that offer on the market products with low technological sophistication and that have relation to the local culture. Transformation of the product occurs in a way often handmade and informal in small installations. Mostly they involve simple processing, low-tech, but that add significant value. The consumers are from distinct social levels in markets, in addition to meeting the local and regional markets. The main purpose of these establishments has economic nature, through the value aggregation to the products. In the matter of the most prominent social motivations, stand out the fixation of the producer on the farm, and the maintenance of the familiar integrity through the involvement of everyone on the production (RUIZ et al., 2002). 
Other characteristics that outstand in this sector are: technological support usually comes from the own family of the producer or from the development agent; the products in this segment are, in general, little competitive due to small production scale and poor attention given to the presentation of the products to the consumer regarding to packaging, labels and symbols; the producers often face problems to place their products in different markets, since the niches and opportunities were not duly and previously analyzed; the estimated survival rate of these enterprises is about 3\%; the failures occur, in most times, as result of lack of proper planning and also by having little adaptation capacity to the frequent economic changes (RUIZ et al., 2002). However, this sector faces difficulties, especially related to the formalization and market.

\section{MATERIALS AND METHODS}

The methodology of this quantitative and qualitative research project was a multiple case study. The study focused on agro-industries from the northern region of the state of Rio Grande do Sul and their customers. Nine agro-industry enterprises, each considered economically and socially important and identified by EMATER (Technical Assistance and Rural Extension Company, in Portuguese Empresa de Assistência Técnica e Extensão Rural), regional Passo Fundo, as representative of the region, were studied. As instruments, the research used a questionnaire and an interview, conducted with both enterprises' representatives and their direct consumers/buyers (i.e., the downstream sector).

Table 1 summarizes the main characteristics of the studied enterprises, demonstrating the kinds of industrialized agro-products, locations, and municipality sizes, and identifying the number of interviewed people.

For data analysis, the ImportancePerformance Matrix elaborated by SLACK (2002) was used. The highlighted matrix works as follows: first, the scale of "importance" is established. It indicated how customers see the relative importance of each of the competitive criteria previously established (i.e., the goal of the "importance" scale is to highlight the criteria

Table 1 - Relationship of family farms studied and correspondents interviewed consumers as well as location and products produced.

\begin{tabular}{|c|c|c|c|c|}
\hline Agro-industry & Product & Municipalities & $\begin{array}{l}\text { Inhabitants of the } \\
\text { Municipality }\end{array}$ & Consumers Interviewed \\
\hline 1 & $\begin{array}{l}\text { Salami, Tuscan sausage, } \\
\text { and campeira sausage }\end{array}$ & Erebango & 2.970 & $\begin{array}{l}\text { Totality of buyers - Three small and } \\
\text { medium-sized supermarkets }\end{array}$ \\
\hline 2 & $\begin{array}{l}\text { French Bread, milky and } \\
\text { house made for school } \\
\text { lunch, cakes, cookies, } \\
\text { sweets and snacks }\end{array}$ & $\begin{array}{l}\text { Getúlio } \\
\text { Vargas }\end{array}$ & 16.154 & $\begin{array}{c}\text { Totality of buyers - Two bakeries and a } \\
\text { school. }\end{array}$ \\
\hline 3 & Honey & Sertão & 6.294 & $\begin{array}{l}\text { Totality of buyers - Three small and } \\
\text { medium-sized supermarkets }\end{array}$ \\
\hline 4 & $\begin{array}{l}\text { Colonial cheese, rennet } \\
\text { cheese, seasoned and } \\
\text { minas, milk drinks, ricotta, } \\
\text { doce de leite, cream }\end{array}$ & Passo Fundo & 179.630 & $\begin{array}{l}\text { Final consumers in Passo Fundo } \\
\text { Farmers Fair (42 interviews) }\end{array}$ \\
\hline 5 & Cornbread, cookies & Passo Fundo & 179.630 & $\begin{array}{l}\text { Final consumers in Passo Fundo } \\
\text { Farmers Fair ( } 37 \text { interviews) }\end{array}$ \\
\hline 6 & Medicinal plants & Passo Fundo & 179.630 & $\begin{array}{l}\text { Final consumers in Passo Fundo } \\
\text { Farmers Fair ( } 21 \text { interviews) }\end{array}$ \\
\hline 7 & $\begin{array}{c}\text { Salami, sausage, meat, } \\
\text { bacon, Calabrese sausage, } \\
\text { lard }\end{array}$ & Passo Fundo & 179.630 & $\begin{array}{l}\text { Final consumers in Passo Fundo } \\
\text { Farmers Fair ( } 65 \text { interviews) }\end{array}$ \\
\hline 8 & $\begin{array}{l}\text { Canned fruits and } \\
\text { vegetables }\end{array}$ & Passo Fundo & 179.630 & $\begin{array}{l}\text { Final consumers in Passo Fundo } \\
\text { Farmers Fair ( } 24 \text { interviews) }\end{array}$ \\
\hline 9 & $\begin{array}{c}\text { Cookies, bread, cucas, } \\
\text { pastry, massas, pizzas, } \\
\text { cakes }\end{array}$ & $\begin{array}{l}\text { Floriano } \\
\text { Peixoto }\end{array}$ & 2.018 & $\begin{array}{l}\text { Totality of buyers - Three small and } \\
\text { medium-sized supermarkets }\end{array}$ \\
\hline
\end{tabular}


most valued by clients). Conversely, the "performance" scale aimed to identify, from the perspective of the enterprises analyzed, how a company is performing in comparison with its competition (i.e., each performance goal is compared to the levels achieved by competitors, to identify whether the company is excelling or underperforming).

Slack's Matrix is composed of four areas, called zones, which are defined as: a) the excess zone, where the company's performance in a given competitive dimension far exceeds the importance given by the customer; b) the appropriate zone, where there is agreement between the importance of the criteria given by the client and the company's performance relative to competitors; c) the improvement zone, where the company's performance in relation to the criteria needs improvement; and d) the urgent action zone, where it is urgent that the company improve in relation to the criteria, because of the importance customers place on the criteria and the low performance of the company.

As pointed out by SLACK et al. (2008) the application of the matrix occurs on the measure that it provides an assessment of each competitive factor and its respective position in relation to their performance. Thus, the priority for improvement that should be given to each competitive factor can be evaluated based on their importance and performance (SLACK et al., 2008: 598). That is, through a matrix importance-performance, as the name indicates, each competitive factor is positioned according to their scores or ratings on these criteria.

The data were collected through questionnaires, in which the interviewed people assessed the company's position in comparison to its competitors, on an evolutionary line ranging from one (1) to 9 (nine), where 1 is the highest score and 9 is the least satisfactory. To systematize the data gathered from the importance and performance evaluations for each agro-industry company, averages were calculated. After plotting the averages on the matrix, a detailed analysis of the problem areas, located in the excess, improvement, and urgent action zones, was performed.

The interviews were conducted vis-à-vis, with agroindustries and their respective buyers. The questionnaires contained closed questions and the analysis criteria were based on research previously developed on the area by KOHLS (2004).

\section{RESULTS AND DISCUSSION}

This section presents the main results obtained from the research. The importance and performance scales will be assessed jointly from the data of the nine agro-industry enterprises by analyzing the averages for each item in relation to the matrix, in an attempt to give an overview of the agroindustry enterprises in the region. Then, an attempt to verify the compliance of the strategic orientation will be conducted, correlating strategic orientation with the position reported in the matrix.

The analysis seems reliable, because the standard deviations around the mean values were low (1.20 to 1.47 for importance and performance, respectively). It is noteworthy that twenty criteria were defined to compose the analysis, and for each criteria consumers gave a significance; later, these same criteria were analyzed from the performance point of view (i.e., how each agro-industry analyzes its performance for each criteria when compared to main competitors).

The figure 1 shows the result of the comparison between the analysis of the importance and the performance, being the importance evaluated by the buyers and the performance by the comparison with the main competitors. Stood out that the closer to zero, greater the importance and performance of the conditioners analyzed. Out of the twenty items taken into account at the moment of the analysis, costumers elected as the most important factors: specification, better prices, fast answer to non scheduled orders, fast delivery, negotiation condition, replacement of losses and delivering deadlines. Regarding to the performance, it is observed that, on the average, the agroindustries present superior performance to competitors especially on the following conditioners: specification, fast delivery, negotiation condition, products launch, brand image, replacement of losses and delivering deadlines. Conversely, the analyzed agroindustries are not competitive concerning to prices and fast answer to non scheduled orders. Because these factors were pointed out as important by the consumers and the agroindustries have low performance. It was reported that the enterprises waste resources by investing in products launch and brand image, attributes considered not important by the consumers, and that the enterprises have superior performance to competitors.

When the data is interpreted in the light of the Slack's Matrix, it is possible to see that; although, the competitors showed superior performance in six items, the performance of the analyzed agro-industry enterprises is adequate, and reaches neither the excess zone nor the urgent action zone in terms of use of resources. Figure 2 shows that some items are located in the improvement zone, and it is important to pay 


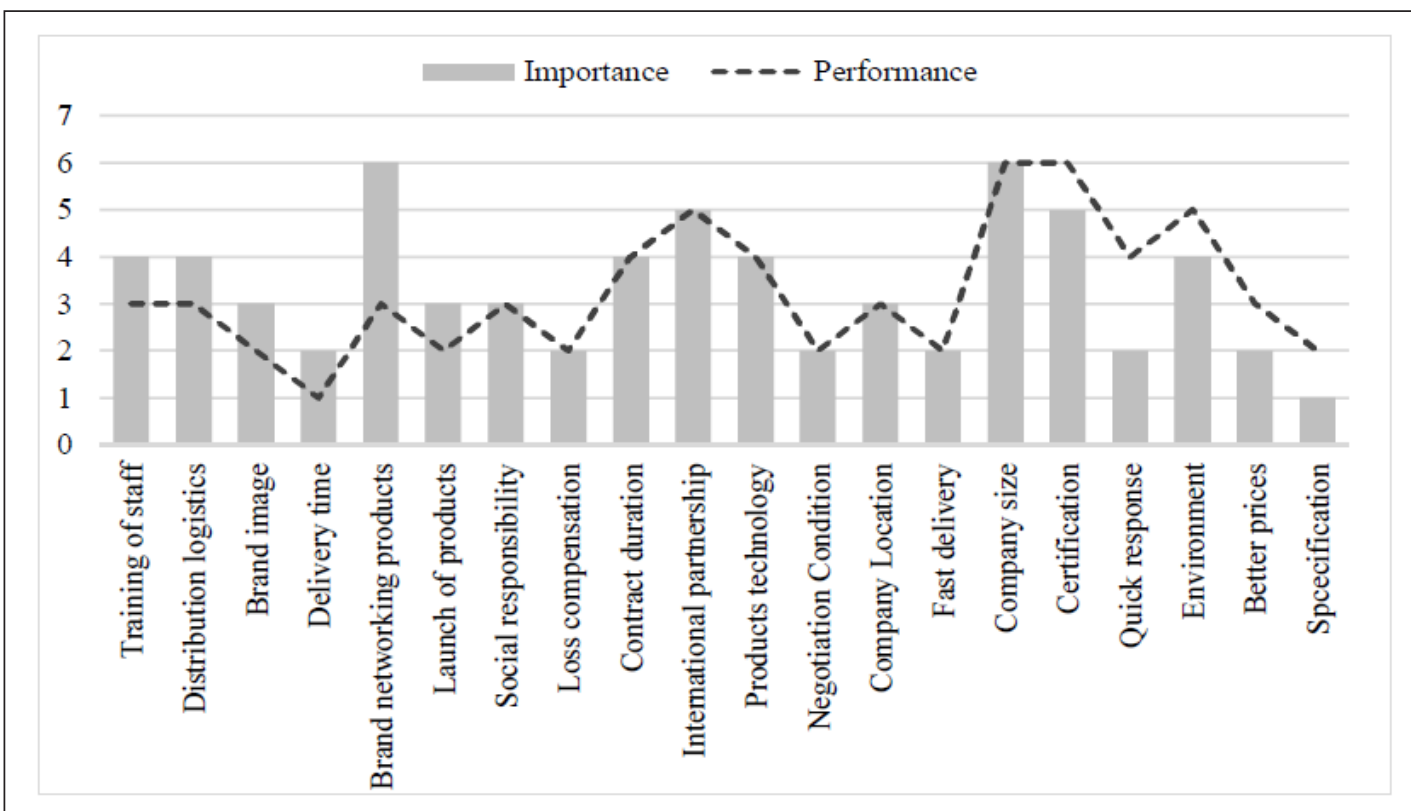

Figure 1 - Importance versus performance relationship in family agro-industries in the Northern Region/RS.

attention to the enterprises' sizes, lack of product certification, preservation actions of the environment, and ability to respond quickly to orders.

The application of the matrix shows that the surveyed agro-industry enterprises present higher performance than demanded (or than attributed importance by customers) for most verified questions. Just four items are located in a zone that indicated a need for improvement, and these items deserved special attention if enterprises wish to reduce the "gap" between the buyers' demands and the enterprises' ability to satisfy them.

The absence of items in the excess zone and urgent action zone reveals a satisfactory situation with regard to external demands. The average performance shows that sixteen (16) points analyzed are located in the zone considered adequate, while only four (4) items are in the range requiring improvement. To arrive at a more complete understanding, facts regarding some specific cases that led to positions within the matrix are presented.

Although the analysis has focused on family agro-industry enterprises, the final products of these enterprises compete with those of larger enterprises (item "company size"), including both national and international businesses. These competitor enterprises have, in general, larger and more flexible structures than the agro-industry enterprises, and they often have longer histories in the market. These differences are reflected in superior know-how in some areas that are also valued by the downstream sector of the processing industry. This is the case with product certifications and quick responses to orders.

Regarding environmental preservation actions, more traditional enterprises that have longer histories in the market realized that this factor was valued by certain consumers and bet on these actions as a strategy to make competitive gains. Conversely, family agro-industries; although, have a smaller environmental impact, have not touted preservation actions as an advantage in advertising campaigns.

Finally, the analysis calls attention to the location of two factors: 1) size of the company (located in the improvement zone) and 2) better prices (located on the border between the appropriate performance zone and improvement zone). These elements are crucial when considering family agroindustry enterprises; therefore, they might have a strategic orientation in the differentiation of their products. Due to their size, though, the surveyed enterprises do not have the scale of large agroindustrial and/or multinational conglomerates, and do not have the option of adopting a generic cost strategy. Understanding that the source of competitive advantage is crucial, because such an understanding 


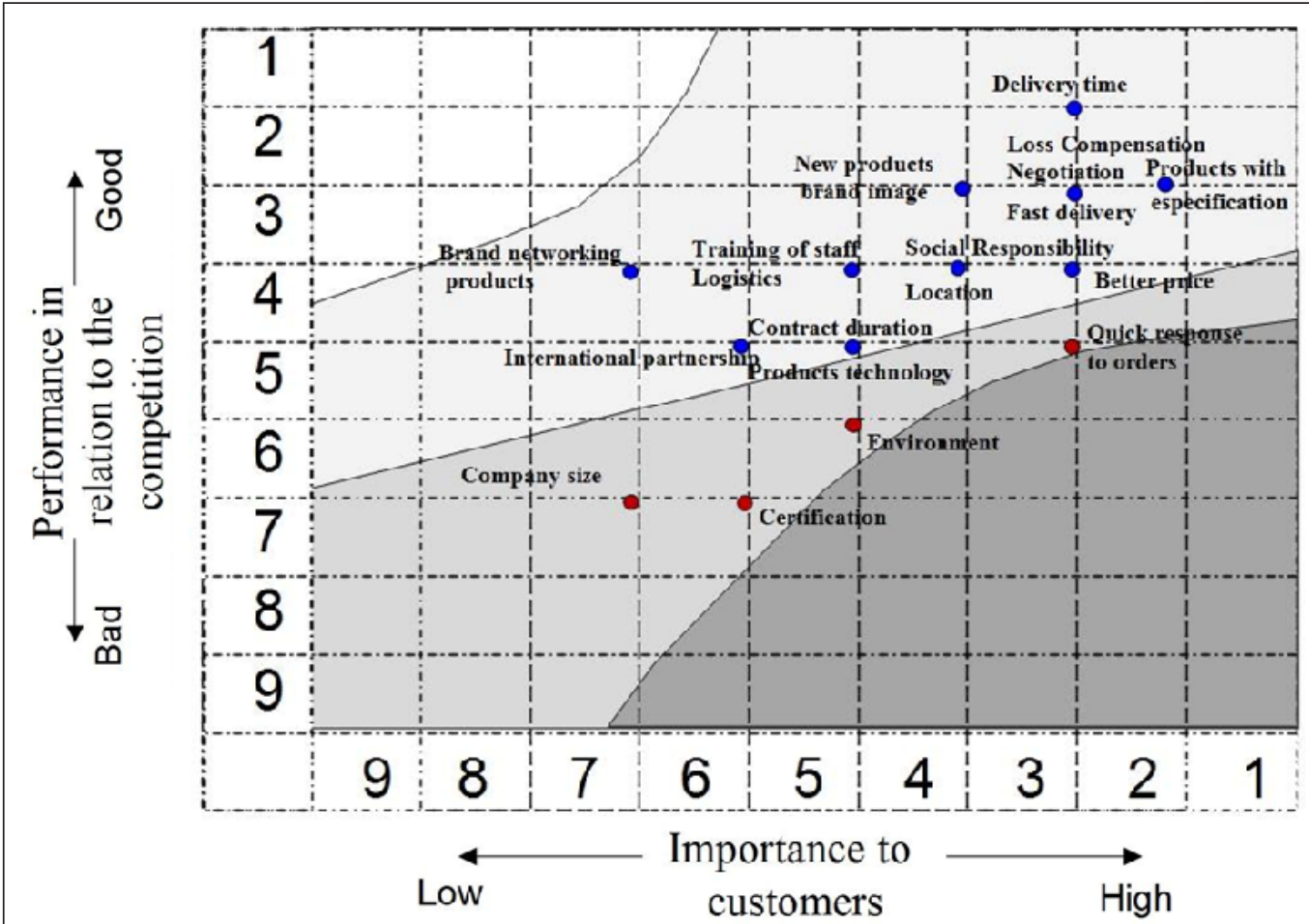

Figure 2 - Analysis of the strategic position of family agro-industries examined as from the Slack's matrix.

can help enterprises avoid mistakes when identifying the focus areas for solving problems.

To support the discussions of the figures 1 and 2 we used the average of the values reported and that, this does not always represents the particularities of the analyzed agroindustries. To compensate this debility, the main particularities were cited throughout the research. The analyzed enterprises; although, they are all family agro-industry enterprises, display different market characteristics, such as, for example, the fact that some commercialize their products in market places (direct) while others only have a few buyers who resell in their stores (intermediaries), which influence the analysis. As a common factor, such organizations occupy different market spaces and, therefore, escape direct competition between enterprises (i.e., increased competition and rivalry). These enterprises connect with specific consumers, who are interested in products produced regionally, with a link to the rural, and to the countryside, which is the competitive advantage of these agroprocessing enterprises. In this sense, the market structure facing these analyzed enterprises is one of low competition.
To PORTER (1986: p.51) “[...] to differentiate the product or service offered by the company, creating something that is considered unique on the scope of the entire industry." Thus, size and price are items closely related to the profile of the family agribusiness, and which are not very flexible because of their "design." Accordingly, it is strongly recommended that these enterprises focus their attention on certification, care for the environment, and rapid response to orders. If executed effectively, these factors could even expand and improve on the differentiating factor of these agroprocessing enterprises, which is that they are geographically closer to their consumers, as compared to multinationals.

\section{CONCLUSION}

The main result of this research emphasized that the strategic direction of the analyzed agroprocessing enterprises is focused on differentiation, presenting, in most of the studied items, congruence with the demands 
of consumers. This means that their position is not at a disadvantage when compared to their competitors for most of the criteria that are considered fundamental for consumers when deciding to place an order.

Except for four criteria located in the improvement zone, the studied items are within the appropriate zone. This means that the criteria considered important by consumers are also a priority in the strategic actions of the analyzed agroprocessing enterprises.

The criteria (i.e., employee training; distribution logistics; brand of products; duration of contracts; partnerships; technology of products; company size; product certification; and relationship of the company with the environment) were considered as being the most important criteria for consumers. The following aspects required improvement for family agro-industry enterprises: certification, care for the environment and rapid response to orders. If removed from the improvement zone, these requisites might enlarge the differentiating factor of these agroprocessing enterprises.

\section{BIOTHICS AND BIOSSECURITY COMMITTEE APPROVAL}

We, as authors of the article "Perception of performance and importance to consumers of the family agro-industry of the northern region of Rio Grande do Sul," declare for due purposes that the project from which the data has originated, was not submitted for evaluation to the Ethics Committee of the Federal Institute of Education, Science and Technology of Rio Grande do Sul. Nevertheless, we are aware of resolution number 466 of 12 December, 2012, of the National Health Council <http://conselho.saude.gov. br/resolucoes/2012/Reso466.pdf $>$ if research involves humans.

Thus, the authors assume full responsibility for the data presented and are available to answer further questions, if required by the competent bodies.

\section{REFERENCES}

AZEVEDO, P. F. Concorrência no agribusiness. In: ZYLBERSZTAJN, D.; NEVES, M.F. (Orgs.). Economia e negócios agroalimentares. São Paulo: Pioneira, p.59-79, 2000.

BREITENBACH, R.; SOUZA, R.S. Market characterization and governance structure in the production chain. Organizações Rurais \& Agroindustriais, Lavras, v.13, n.1, p.77-92, 2011. Available from: $<$ http://ageconsearch.umn.edu/bitstream/133911/2/6\%20Artigo \%20 09.499.pdf $>$. Accessed: Sept. 01, 2015.

HEIDTMANN JUNIOR, D. E. D.; LOCH, C. The cultural landscape and the new possibilities for rural family activity. Ciência Rural, Santa Maria, v.44, n.11, p.1988-1994, 2014.

KOHLS, V.K. As ênfases estratégicas de empresas agroalimentares: estudo de caso na região de Pelotas-RS. Tese (Doutorado em Administração) - Escola de Administração, PPGA/UFRGS, 2004. 238p.

LISBOA, R. et al. Como sobreviver e crescer num mercado competitivo: análise das estratégias de uma empresa processadora de arroz. In: CONGRESSO DA SOBER, 47, 2009, Porto Alegre, Brasil. Anais... Porto Alegre: UFRGS, 2009. Available from: <http://www. sober.org.br/palestra/13/977.pdf. $>$. Accessed: Sept. 01, 2015.

MIOR, L. C. Agricultores familiares, agroindústrias e redes de desenvolvimento rural. Chapecó, SC: ARGOS, 2005. 5p.

PORTER, M.E. Estratégia competitiva: técnicas para análise de indústrias e da concorrência. Rio de Janeiro: Campus, 1986. 409p.

Vantagem competitiva: criando e sustentando um desempenho superior. Rio de Janeiro: Campus, 1989. 512p. RUIZ, M. S. et al. Agroindústria familiar de Londrina (PR). UNOPAR Científica Ciências Jurídicas E Empresariais, Londrina, v.3, n.2, p.7-13, 2002. Available from: <http://pgsskroton.com.br/ seer/index.php/juridicas/article/viewFile/1401/1344.> Accessed: Jan. 15, 2016.

WILKINSON, J. Mercados, redes e valores: o novo mundo da agricultura familiar. Porto Alegre: UFRGS, 2008. 216p.

WOOD J. R. T.; CALDAS, M.P. Empresas brasileiras e o desafio da competitividade. Revista Administração de Empresas [online], v.47, n.3, p.1-13, 2007. Available from: <http://www.scielo.br/pdf/ rae/v47n3/v47n3a06.pdf>. Accessed: Jun. 10, 2015.

SLACK, N. Vantagem competitiva em manufatura: atingindo competitividade nas operações industriais. Tradução Sônia Maria Correia. Revisão Técnica Henrique Luiz Corrêa. 2.ed. São Paulo: Atlas, 2002. 218p.

SLACK, N. et al. Administração da produção. Tradução Maria Teresa Correia de Oliveira. Revisão Técnica Henrique Luiz Corrêa. 2.ed. São Paulo: Atlas, 2008. 728p. 